\title{
A subaerial stromatolite from the Lower Carboniferous of South Wales
}

(Plate 1)

SIR - In recent years, there has been increasing interest in the recognition of subaerial exposure phenomena in ancient limestone sequences. The correct identification of subaerial features, such as calcretes, has enabled many hidden breaks to be recognized in apparently uniform sequences. Many such calcretes had previously been interpreted as stromatolites and the differentiation between stromatolites and calcrete crusts became a focus of much attention (e.g. Read, 1976). Recently, Klappa (1979a) attributed the formation of some types of laminated calcrete crust to the activities of lichens. Subaerially exposed limestone is often colonized by lichens which, as a result of successive cycles of growth and diagenesis, form laminated structures called lichen stromatolites by Klappa (1979a, p. 398). Krumbein \& Giele (1979) described laminated crusts (calcrete) from California and Israel, forming at the present day, as the result of the calcification of the coccoid cyanobacterium Pleurocapsa $\mathrm{sp}$. They termed these crusts desert stromatolites. Thus the wheel has turned full circle from a time when stromatolites were re-interpreted as calcrete crusts to the present when some calcrete crusts are being re-interpreted as subaerial stromatolites. The question arises as to whether such subaerial stromatolites can be recognized in ancient limestone sequences and what criteria are suitable for their recognition.

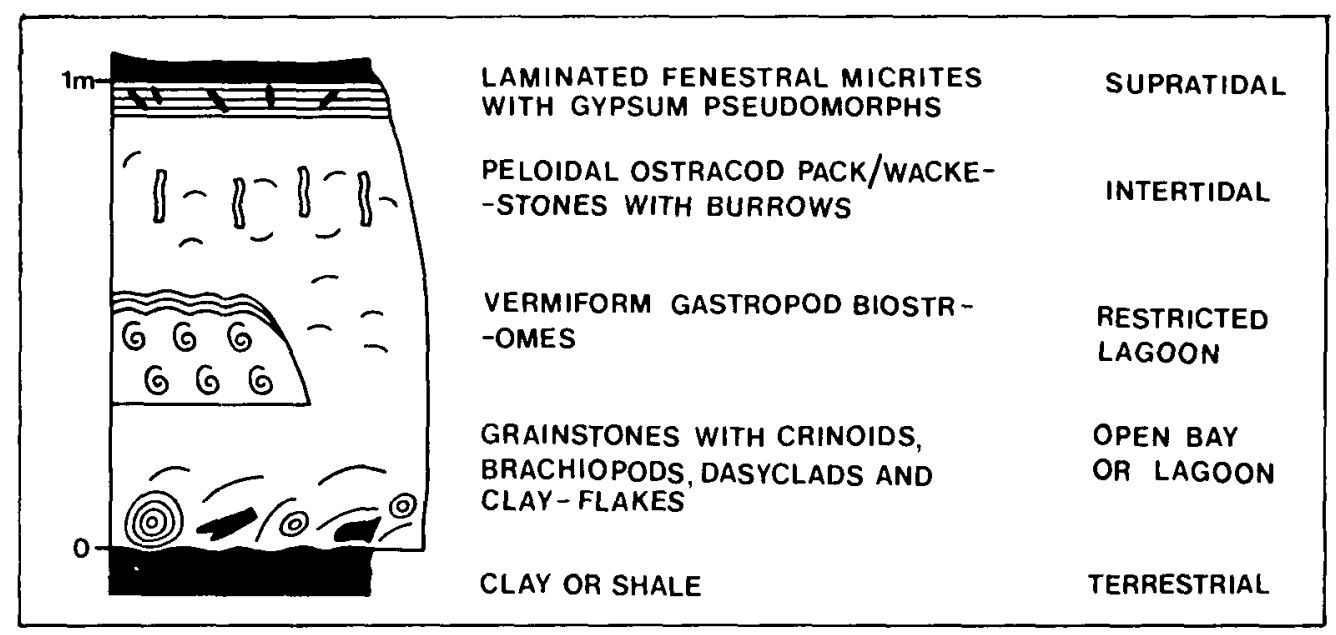

Figure 1. A complete shoaling bay unit from the Llanelly Formation. The subaerial stromatolite described caps one such unit.

A variety of subaerial and pedogenic features occur in the Llanelly Formation (George et al. 1976) of Lower Carboniferous age, in South Wales. This unit consists, in part (Fig. 1) of a series of cyclic limestones which represent shoaling bay facies. Many of the cycles are capped by laminated micrites with gypsum pseudomorphs while others are capped by green clays and shales with nodular and platey calcretes representing palaeosols (Wright. 1980). One cycle is capped by a distinctive laminated crust (Plate $1 a, b), 1 \mathrm{~m}$ below the Linoproductus Oolite of George (1954). The crust occurs at the Clydach Lime Works (British Grid ref. SO 21.235,127), Llanelly Quarry (SO 21,224,125) and Craig y Gaer (SO 21,224,134) in the Clydach Gorge near Brynmawr, Gwent (see details in George, 1954).

The cream- to buff-coloured crust is $2-5 \mathrm{~cm}$ thick and is very finely laminated. The individual laminae, up to $200 / / \mathrm{m}$ thick, are of two types; dark, micritic laminae, and cloudy, fine spar laminae. The micritic laminae are continuous to irregular in form and often highly contorted. They sometimes display clotted textures and frequently contain large septate, sinuous, micrite-walled tubes up to

0016-7568,81/2828-6190\$01.00 (c) 1981 Cambridge University Press

Geol. Mag. 118 (1), 1981, pp. 97-100. Printed in Great Britain. 
$100 \mu \mathrm{m}$ (Plate $\mathrm{le}$ ) in diameter but averaging $40-60 \mu \mathrm{m}$ wide. The walls of the tubes are up to $10 \mu \mathrm{m}$ thick. The cloudy spar laminae have a continuous to highly irregular form and often appear stromatolitic, i.e. the laminae are domed, above a flat substrate, and are not related to the underlying micro-topography as would be the case if the laminae were purely accretionary (Plate $1 f$ ). The sparry calcite is very cloudy in appearance, but is not pseudopleochroic and in patches it appears very finely fibrous. It contains 'floating' peloids, $50-200 \mu \mathrm{m}$ in diameter, which are often surrounded by a crust of fibrous calcite (Plate $1 c, f$ ) which superficially resemble thrombolitic fabrics (Monty, 1976, figs 28,29 ). Poorly preserved tubes, averaging $25-30 \mu \mathrm{m}$, are common in these laminae but lack well-defined walls (Plate 1 c). Tubular, spar-filled fenestrae, up to $700 \mu \mathrm{m}$ in diameter and $2000 \mu \mathrm{m}$ long, are common in both types of laminae, with the laminae bulged out around these larger tubes. Many of the tubes have micrite walls (Plate I $d$ ) up to $50 \mu \mathrm{m}$ in thickness. Smaller, irregular fenestrae also occur (Plate $1 c, d$ ).

The crust overlies a peloidal grainstone with well-developed micrite coatings on the peloids and tubular fenestrae similar to those in the crust but displaying arcuate cross-walls similar to alveolar texture (Esteban, 1974). The contact between the crust and the underlying limestone consists of peloids set in a micritic matrix passing down into peloids with grain coats.

The crust superficially resembles a normal stromatolite but is quite different in fabric from other stromatolites and coniatolites in the Llanelly Formation. The form of the lamination, often domed or even apparently tufted (Plate $1 f$ ), the presence of fine calcareous tubes and clotted textures strongly suggests a stromatolitic origin for the crust. Calcareous tubes, however, are also a typical feature of calcrete crusts (James, 1972; Ward, 1975; Harrison, 1977; Klappa, 1979b) and are formed by the calcification of root hairs, actinomycete and fungal hyphae, cyanophytes and chlorophytes. Considering the large diameters of these Carboniferous tubes (cf. Klappa, 1979b) they are unlikely to be calcified actinomycete or fungal hyphae, which are usually less than $10 \mu \mathrm{m}$ in diameter. The sizes given by Klappa for angiosperm root hairs are obviously not directly applicable to the Carboniferous, but there appears to be no relationship between the fine calcareous tubes and the root tubes (see later) in the crust which might suggest that they are root hairs (Ward, 1975, p. 522). The sizes quoted by Ward (1975) and Klappa (1979b) for calcified chlorophytes and cyanophytes in Recent calcretes are rather on the small side when one considers the size of such calcified algae in other environments (Monty, 1976; Riding, 1979) and it seems likely that these fine tubes were formed by calcified chlorophytes and/or cyanophytes. The clotted fabrics are a less clear aspect but may well be comparable to 'thrombolitic', calcified coccoid algae (Monty, 1976). Thus it appears that there was a strong, indeed dominant, algal influence in the genesis of the crust.

The coated grain and alveolar texture in the underlying limestone are diagnostic and typical calcrete fabrics (James, 1972; Harrison, 1977; Esteban, 1974). The coarse tubular fenestrae in the crust are strikingly similar to root voids described in Recent calcretes (Harrison, 1977) and the alveolar textures also owe their origin to root activity (ibid.). Thus the crust possesses both algal and pedogenic features while the underlying limestone contains diagnostic pedogenic fabrics. The observation that the crust overlies pedogenically modified limestone and is cross-cut by root voids clearly suggests that it had a similar pedogenic origin, yet the crust appears truly stromatolitic in origin. The conclusion one must draw is that the stromatolite is pedogenic and formed in a subaerial environment. The crust lacks the diagnostic features listed by Klappa (1979a) for lichen stromatolites, and Krumbein \& Giele (1979) gave few petrographic details of their desert stromatolites with which to compare the Carboniferous crust. In any case the term desert stromatolite is avoided here with its connotations of extreme aridity and a lack of vegetation. The term subaerial stromatolite is preferred to describe bona fide stromatolites formed in a subaerial environment and in association with other subaerial phenomena including karst and palaeosols. This term would encompass both Klappa's lichen stromatolites and Krumbein and Giele's desert stromatolites.

The Carboniferous crust bears a striking resemblance to the caliche-algal micrite crusts described from the Recent of the Isla Mujeres, Quintana Roo, Mexico by Ward, Folk \& Wilson (1970). These problematical Recent crusts, which consist of laminated micrite and organic material with both caliche and algal characteristics, are here by analogy re-interpreted as a subaerial stromatolite.

In conclusion, it seems that calcretes built by micro-organisms can be recognized where there is a clear association of demonstrably pedogenic and biogenic features in intimate association. Indeed, such stromatolites can be recognized in the Lower Carboniferous, and it is interesting to speculate that such communities would have provided an ideal environment for the colonization of the lichen-building ascomycete fungi which appeared later in the Carboniferous (Tiffney \& Barghoorn. 1974). 


\section{References}

Esteban, M. 1974. Caliche textures and Microcodium. Boll. Soc. geol. ital. 92 (suppl. 1973), 105-25. George, T. N. 1954. Pre-Seminulan Main Limestone of the Avonian series in Breconshire. Q. Jlgeol. Soc. Lond. 110, 283-322.

George, T. N., Johnson, G. A. L., Mitchell, M., Prentice, J. E., Ramsbottom, W. H. C., Sevastopulo, G. D. \& Wilson, R. B. 1976. A correlation of Dinantian rocks in the British Isles. Geol. Soc. Lond. Special Report No. 7.

Harrison, R. S. 1977. Caliche profiles: indicators of near-surface subaerial diagenesis, Barbados, West Indies. Bull. Can. Petrol. Geol. 25, 123-73.

James, N. P. 1972. Holocene and Pleistocene calcareous crust (caliche) profiles: criteria for subaerial exposure. J. sedim. Petrol. 42, 817-36.

Klappa, C. F. $1979(a)$. Lichen stromatolites: criterion for subaerial exposure and a mechanism for the formation of laminar calcretes (caliche). J. sedim. Petrol. 49, 387-400.

Klappa, C. F. $1979(b)$. Calcified filaments in Quaternary calcretes: organo-mineral interactions in the subaerial vadose environment. J. sedim. Petrol. 49, 955-68.

Krumbein, W. E. \& Giele, C. 1979. Calcification in a coccoid cyanobacterium associated with the formation of desert stromatolites. Sedimentology 26, 593-604.

Monty, C. L. V. 1976. The origin and development of cryptalgal fabrics. In Stromatolites, Developments in Sedimentology, vol. 20 (ed. M. R. Walter), pp. 193-249. Amsterdam: Elsevier.

Read, J. F. 1976. Calcretes and their distinction from stromatolites. In Stromatolites, Developments in Sedimentology, vol. 20 (ed. M. R. Walter), pp. 55-71. Amsterdam: Elsevier.

Riding, R. 1979. Origin and diagenesis of lacustrine algal bioherms at the margin of the Ries crater, Upper Miocene, southern Germany. Sedimentology 26, 645-80.

Tiffney, B. H. \& Barghoorn, E. S. 1974. The fossil record of the fungi. Occas. Pap. Farlow Herb. Cryptogam. Bot. Harv. 7, 1-42.

Ward, W. C. 1975. Petrology and diagenesis of carbonate eolianites of northeastern Yucatan Peninsula, Mexico. In Belize Shelf-carbonate sediments, clastic sediments and ecology (ed. K. F. Wantland \& W. C. Pusey). Am. Assoc. Petroleum Geologists, Studies in Geology no. 2 , $500-71$.

Ward, W. C., Folk, R. L. \& Wilson, J. L. 1970. Blackening of eolianite and caliche adjacent to saline lakes, Isla Mujeres, Quintana Roo, Mexico. J. sedim. Petrol. 40, 548-55.

Wright, V. P. 1980). Climatic Fluctuation in the Lower Carboniferous. Die Naturwissenschaften 67, 252-3.

Department of Geology

V. P. WRIGHT

University College

P.O. Box 78

Cardiff

28 th April 1980 


\section{EXPLANATION OF PLATE}

Plate 1. a. Field aspect of the top of a shoaling bay unit. The hammer marks the position of the subaerial stromatolite. Clydach Limeworks (SO 21,235,127). Hammer head is $20 \mathrm{~cm}$ long.

b. A specimen of the laminated crust described in the text. The base of the crust is arrowed. The dark tubes in the middle of the specimen are root voids with alveolar texture. Scale in $\mathrm{cm}$.

c. Contorted micrite and cloudy calcite spar laminae with a spar-filled root void in the centre. The cloudy spar contains fine algal(?) tubes (filaments), one of which is arrowed. Peloids with fibrous crusts are to be seen in the lower left quadrant. Thin section $\times 14$.

d. Spar-filled root voids. The void in the centre has a micritic wall. Thin section $\times 15$.

e. Algal filaments with distinct cross-walls. The white area is neomorphic spar. Thin section $\times 20$.

f. A tuft structure showing the relationship of algal filaments and the peloidal (clotty) texture. Drawn from a thin section. 
Geol. Mag. Vol. 118, 1981, Wright, Plate 1, facing page 100.
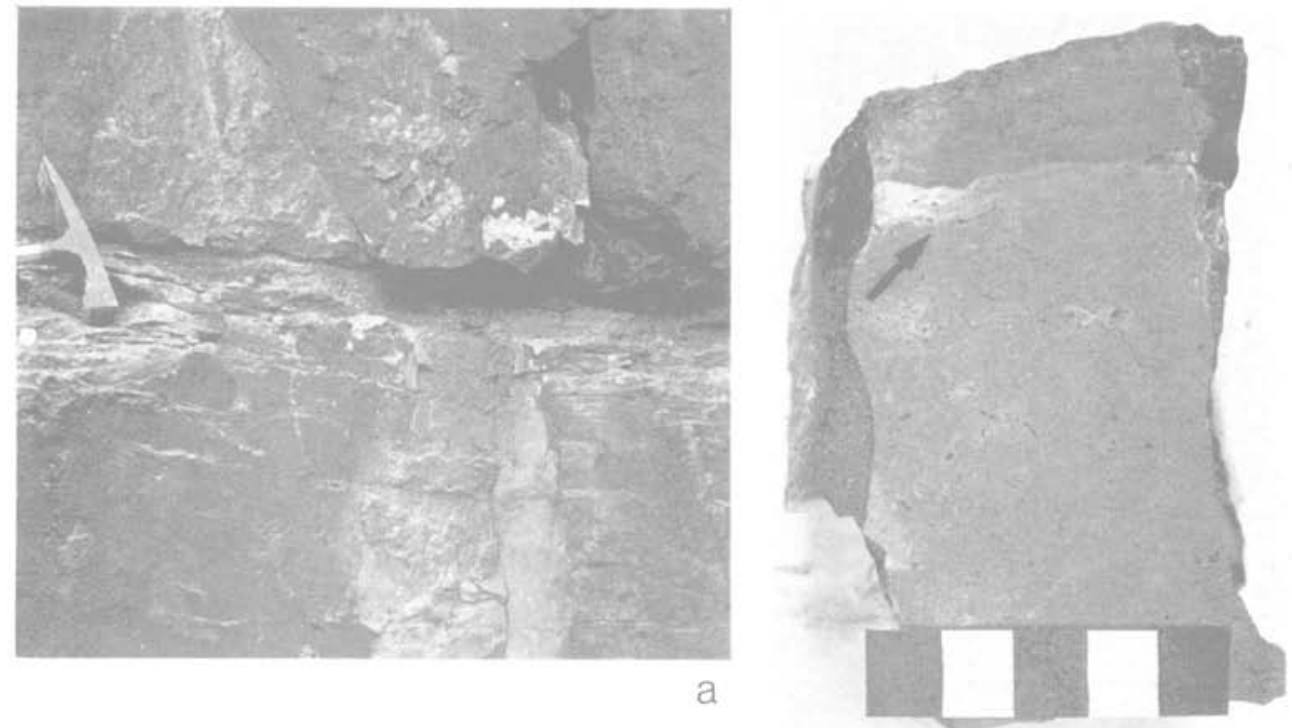

b
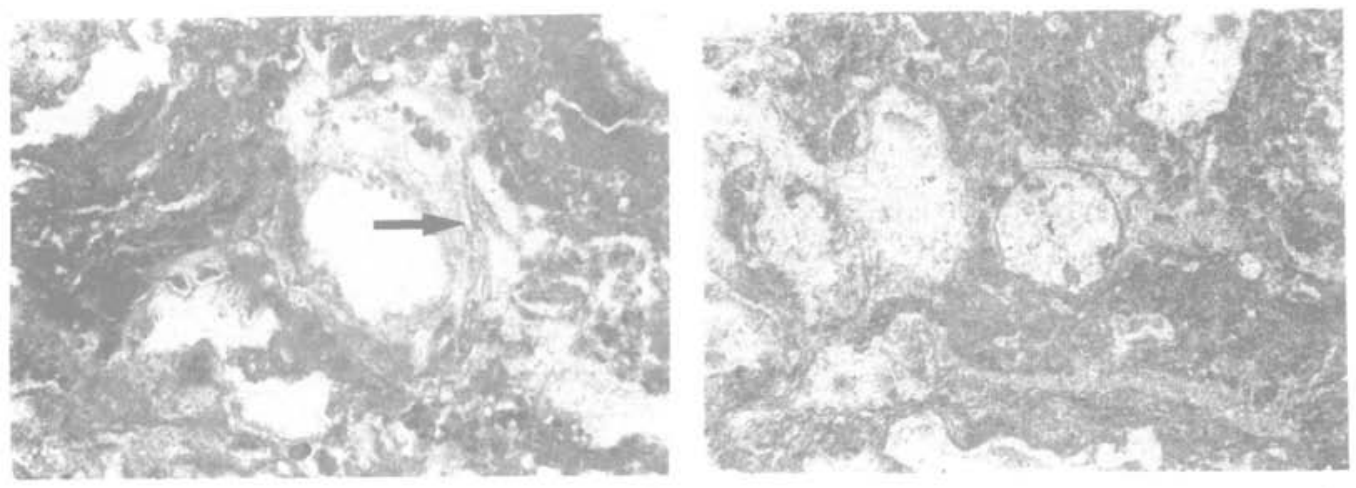

C
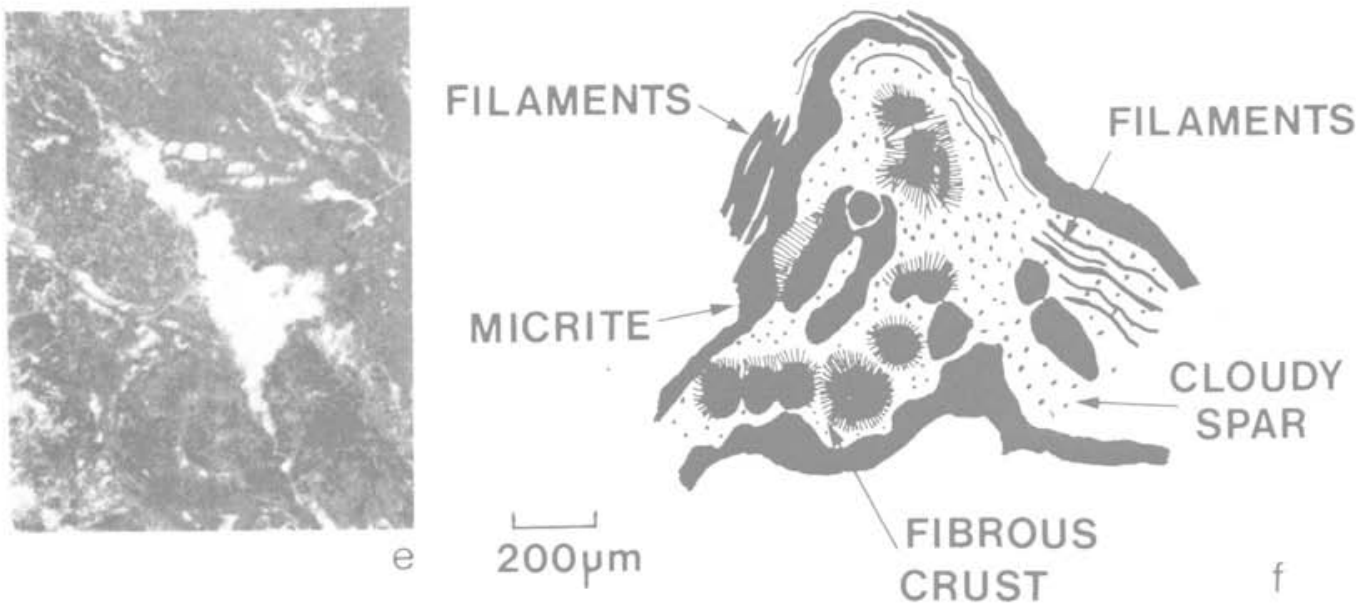

Plate 1. A subaerial stromatolite. 